\title{
Cigarette Smoking and the Effect of Dexmedetomidine and Fentanyl on Tracheal Intubation
}

\author{
Kemal Gulsoy ${ }^{1}$, Serpil Deren ${ }^{1}$, Semih Baskan ${ }^{1}$, Dilsen Ornek ${ }^{1}$, Bayazit Dikmen ${ }^{1}$
}

\begin{abstract}
Summary: Gulsoy K, Deren S, Baskan S, Ornek D, Dikmen B - Cigarette Smoking and the Effect of Dexmedetomidine and Fentanyl on Tracheal Intubation.

Background and objectives: To compare the effect of dexmedetomidine and fentanyl on hemodynamic changes in chronic male smokers.

Methods: This is a prospective, randomized, blinded study. Were selected 60 chronic male smokers (aged 16 to 60 years). The patients were randomly divided into two groups: Group D $(\mathrm{n}=30)$ received $1 \mu \mathrm{g} \cdot \mathrm{kg}^{-1}$ dexmedetomidine and Group $\mathrm{F}(\mathrm{n}=30)$ received $3 \mu \mathrm{g} . \mathrm{kg}^{-1}$ fentanyl in $150 \mathrm{~mL}$ of normal saline, beginning 10 minutes before anesthesia induction. Before intubation, the heart rate and blood pressure of patients were measured. After anesthesia induction for endotracheal intubation, heart rate and blood pressure values were measured at 1, 3, and 5 minutes after intubation.
\end{abstract}

Results: Heart rate was low in Group D before anesthesia induction, intubation, and at the 1st and 3rd minutes after intubation. Systolic arterial pressure was low in Group F before intubation. Although diastolic arterial pressure was lower before anesthesia induction and at 5 minutes after intubation in both groups, it was already low in Group $F$ before intubation. Whereas the mean arterial pressure was low in Group D before anesthesia induction, it was low in Group F before intubation. The values for rate-pressure product were low in Group D before induction and at 1 and 3 minutes after intubation.

Conclusions: Dexmedetomidine, which was applied via infusion at a loading dose of $1 \mu \mathrm{g} . \mathrm{kg}^{-1} 10$ minutes before anesthesia induction in chronic male smokers, better suppressed increases in heart rate and rate-pressure product at 1 and 3 minutes after intubation compared to the group receiving $3 \mu \mathrm{g} . \mathrm{kg}^{-1}$ fentanyl.

Keywords: Dexmedetomidine; Hemodynamics; Intratracheal intubation; Monitoring, Intraoperative; Smoking.

(2012 Elsevier Editora Ltda. All rights reserved.

\section{INTRODUCTION}

Cigarette smoke contains various chemical substances, including nicotine and tar, most of which are carcinogens. Grassi et al. ${ }^{1}$ suggested that smoking increases sympathetic activation due to increased release of catecholamines and the delay in nicotine clearance from the neuroeffector junction. Because smokers experience a high hemodynamic response to anesthesia induction and intubation, serious problems may develop in chronic smokers. The cardiovascular system function varies between genders because the autonomic nervous system is influenced by hormonal and developmental differences between genders. For this reason, response to tracheal intubation is more evident in males ${ }^{2-10}$. Long-term exposure to cigarettes causes an increased response to the mechanical

Received from HM Ankara Numune Training and Research Hospital, Turkey.

1. Anaesthesia and Reanimation Department, Ankara Numune Training and Research Hospital, Turkey

Submitted on May 13, 2011

Approved on June 19, 2011.

Correspondence to:

Dr. Dilsen Ornek

HM Ankara Numune Training and Research Hospital

Ulku Mahallesi Talatpasa Bulvari No: 5

Altindag, Ankara 06100, Turkey

E-mail:dilsenpinar@yahoo.com stimulation caused by laryngoscopy and intubation. Hemodynamic response, which develops secondary to laryngoscopy and tracheal intubation, include heart rate, catecholamine level, blood pressure, and rate-pressure product ${ }^{2-10}$.

Anesthesiologists have focused on controlling secondary responses to laryngoscopy and intubation. For this purpose, several drugs were used, including lidocaine, opioids, sodium nitroprusside, nitroglycerine, $\alpha-2$ agonists, $\beta$ blockers, and calcium channel blockers ${ }^{1-11}$.

Although opioid analgesics are widely used to minimize acute increases in blood pressure and heart rate during anesthesia induction, they have side effects, such as respiratory depression, muscular rigidity, and delayed recovery from anesthesia. Opioid analgesia also causes sympatholysis and an increased vagal activity as a result of the central effect of dexmedetomidine, which is a selective $\alpha-2$ agonist. It also further increases the sympatholytic effect due to its peripheral potency ${ }^{1-11}$.

Therefore, in this study, the effect of dexmedetomidine, which is used to block efferent pathways and effector receptors, was compared with the effect of fentanyl, which is used to block the central effects of sensorial pathways on hemodynamic changes. The subjects were chronic male smokers, thus representing the population in which secondary response to laryngoscopy and intubation is most common. 


\section{MATERIAL AND METHODS}

After approval by the local Research Ethics Committee and after obtaining informed consent from all participants, the study was conducted with 60 ASA I-II male patients (aged 18-60 years) who were chronic cigarette smokers. All patients had a body mass index of $30 \mathrm{~kg} \cdot \mathrm{m}^{-2}$; were all normotensive and receiving no medication; with Mallampati classification I-II; and requiring endotracheal intubation involving elective surgical interventions. To qualify as chronic smokers, patients had to have smoked for two years at least, and a minimum consumption of 10 cigarettes day ${ }^{-1}$. Patients with hypertension, hypovolemia, history of opioid or sedative drugs, morbid obesity, or ischemic heart disease, and those in whom a difficult intubation was anticipated were excluded from the study. Patients in whom more than one laryngoscopy and intubation attempt had been made or whose laryngoscopy and intubation operation took more than 20 seconds were also excluded.

Patients were divided into two similar groups (30 subjects each) and assigned to receive either dexmedetomidine (Group D) or fentanyl (Group F). A non-invasive blood pressure (NIBP), electrocardiogram (ECG), and pulse oximetry $\left(\mathrm{SpO}_{2}\right)$ monitoring (Datex Ohmeda ADU S/5, Finland) were performed before the patient was taken to the operating room. Afterwards, a 20 gauge intravenous catheter was used to gain vascular access, and Hartmann's solution $5 \mathrm{~mL} . \mathrm{kg}^{-1} \cdot \mathrm{h}^{-1}$ was administered. Ten minutes before anesthesia induction, Group $\mathrm{D}(\mathrm{n}=30)$ was given $1 \mu \mathrm{g} \cdot \mathrm{kg}^{-1}$ dexmedetomidine, whereas Group $F(n=30)$ was given $3 \mu \mathrm{g} \cdot \mathrm{kg}^{-1}$ fentanyl in $150 \mathrm{~mL}$ of normal saline.

After pre-oxygenation for 3 minutes, anesthesia was provided to both groups with $4-7 \mathrm{mg}^{\mathrm{kg}}{ }^{-1}$ thiopental until loss of the eyelash reflex occurred, after which $0.1 \mathrm{mg}^{\mathrm{kg}}{ }^{-1}$ vecuronium was administered. Endotracheal intubation was performed by an anesthesiologist (blinded to the drugs used in infusion); a size 3-4 Macintosh laryngoscope blade and 8-8.5 $\mathrm{mm}$ (internal diameter) disposable tracheal tube was used. The patient's lungs were ventilated with $2 \%$ inhaled sevoflurane and $60 \%$ nitrous oxide in $40 \%$ oxygen via a circle system, and the ventilator frequency was adjusted to a range of 12 to 15 breaths. min $^{-1}$ to maintain end-tidal carbon-dioxide concentration between $4.5-5.0 \mathrm{kPa}$. Hemodynamic parameters were measured as basal values following the first measurement, post-infusion, pre-intubation, and at one, three, and five minutes post-intubation. The measurements were also recorded by an anesthesiologist who was unaware of the drugs being used.

The sample size was calculated based on the assumption that a $20 \%$ difference in heart rate was significant. In accordance with the power calculation method, 18 patients per group should demonstrate a $20 \%$ difference in heart rate value at $\alpha=0.05$ and power of $90 \%$. The primary endpoint was an increase in heart rate after tracheal intubation in both groups. Data analysis was conducted using the SPSS 15.0 software (SPSS Inc., Chicago, IL, USA), and data distribution was controlled using the Levene test. The main variables were percentage heart rate, blood pressure, and rate-pressure product as compared with the baseline figures. Rate-pressure product was obtained by multiplying systolic blood pressure and heart rate. In the intergroup evaluations, an independent $t$ test was used to analyze the normally distributed data, and the Mann-Whitney $\mathrm{U}$ test was used for the data that were not distributed normally. A chi-square test was used to evaluate the non-parametric data. In the intragroup evaluations, paired $t$ tests were used. A probability of $p<0.05$ was established as significant.

\section{RESULTS}

Patient characteristics are shown in Table I. There was no difference between groups regarding age, weight, ASA classification, length of time as smokers, or number of cigarettes consumed daily (Table I).

Heart rates were low in Group D before anesthesia induction $(p=0.000)$ and before intubation $(p=0.18)$, as well as at one $(p=0.000)$ and three $(p=0.003)$ minutes after intubation (Table II, Figure 1). Systolic arterial pressure was low in Group $F$ before intubation $(p=0.018)$; (Table III; Figure 2$)$. Whereas

Table I - Demographic Characteristics of the Study Groups

\begin{tabular}{llll}
\hline Time & $\begin{array}{l}\text { Fentany }^{\mathrm{n}} \\
\text { Mean } \pm \text { SD }\end{array}$ & $\begin{array}{l}\text { Dexmedetomidine }^{\mathrm{n}} \\
\text { Mean } \pm \mathrm{SD}\end{array}$ & $\mathrm{p}$ \\
\hline Age & $38.23 \pm 10.94$ & $35.50 \pm 9.28$ & 0.452 \\
Weight $(\mathrm{kg})$ & $70.40 \pm 9.89$ & $73.40 \pm 8.84$ & 0.283 \\
ASA I/II & $22 / 8$ & $23 / 7$ & \\
$\begin{array}{l}\text { Smoking period } \\
\text { (years) }\end{array}$ & $16.83 \pm 11.71$ & $15.97 \pm 8.55$ & 0.401 \\
$\begin{array}{l}\text { \# of cigarettes } \\
\text { used/day }\end{array}$ & $17.33 \pm 8.13$ & $17.00 \pm 5.17$ & 0.290 \\
\hline
\end{tabular}

$n=30$.

the mean diastolic arterial pressure was lower in Group $D$ before anesthesia induction $(p=0.002)$ and at five minutes after intubation than in Group F $(p=0.049)$, it was low in Group F before intubation $(p=0.006)$; (Table IV; Figure 3 ). Whereas the mean arterial pressure was low in Group $D$ before anesthesia induction $(p=0.007)$, it was low in Group $F$ before intubation $(p=0.006)$. Rate-pressure product was low in Group $D$ before induction $(p=0.000)$ and at one $(p=0.010)$ and 3 $(p=0.017)$ minutes after intubation (Table $V$, Figure 4$)$. In the intragroup evaluation, although a decrease was observed in heart rates, blood pressure, and rate-pressure product in both groups according to the basal values after intubation, there were increases in the first minute after intubation. 


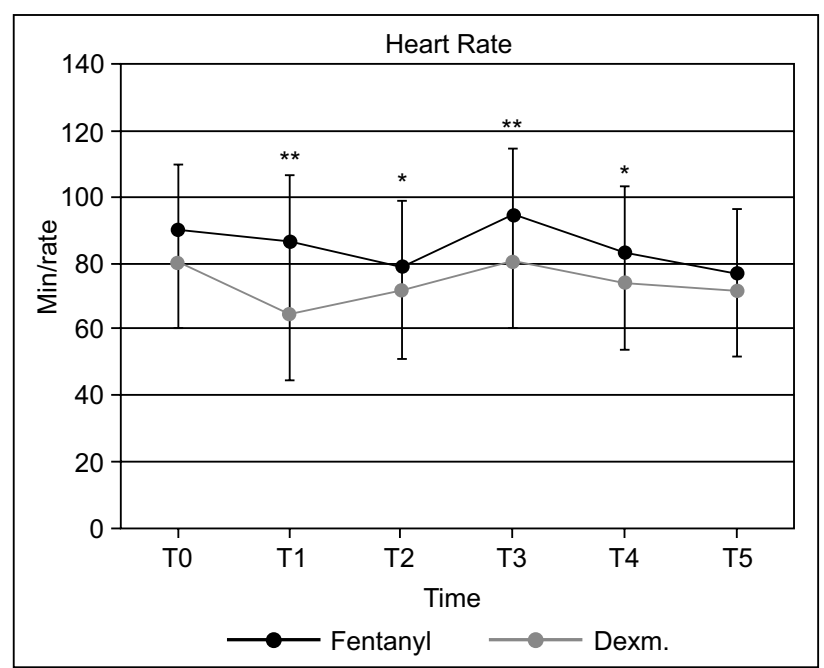

Figure 1 - Intergroup Heart Rate.

* Significantat $p<0.05 ;{ }^{* *}$ Significant at $p<0.001$.

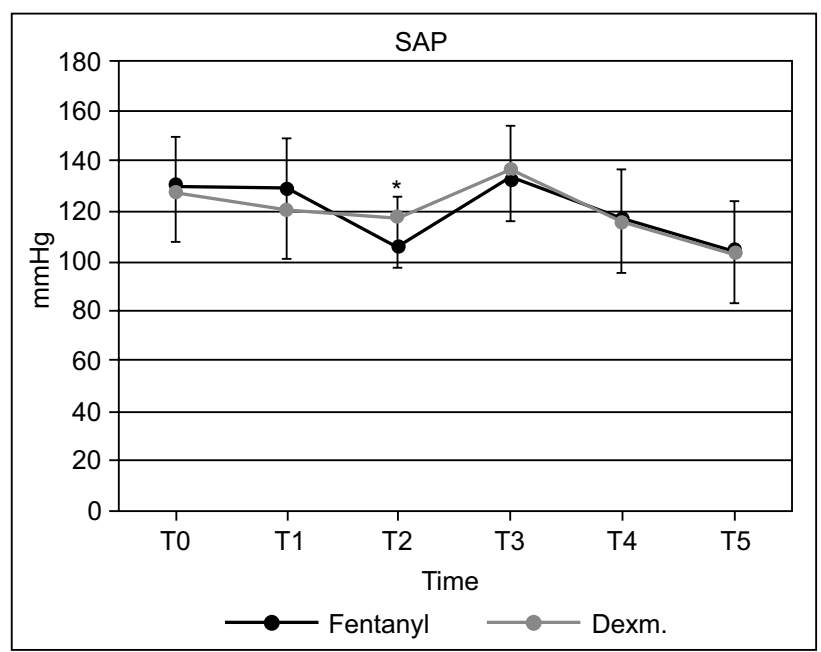

Figure 2 - Systolic Arterial Pressure.

* Significant at $p<0.05$.

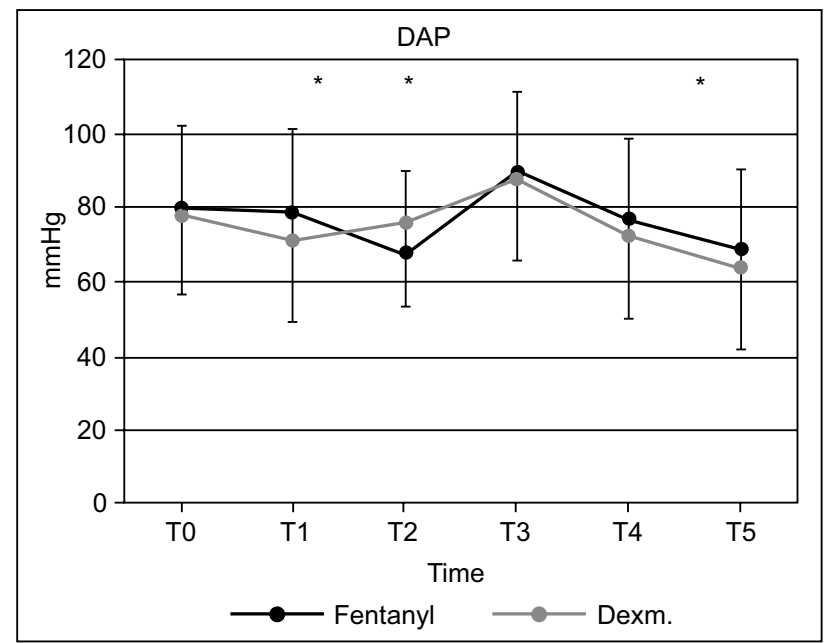

Figure 3 - Diastolic Arterial Pressure.

* Significant at $p<0.05$ level.
Table II - Intergroup Heart Rates

\begin{tabular}{llll}
\hline Time & $\begin{array}{l}\text { Fentanyl }^{\mathrm{n}} \\
\text { Mean } \pm \mathrm{SD}\end{array}$ & $\begin{array}{l}\text { Dexmedetomidine }^{\mathrm{n}} \\
\text { Mean } \pm \mathrm{SD}\end{array}$ & $\mathrm{p}$ \\
\hline Basal values & $84.98 \pm 18.32$ & $81.00 \pm 12.31$ & 0.238 \\
Before induction & $86.40 \pm 18.25$ & $64.47 \pm 10.77+$ & $0.000^{*}$ \\
$\begin{array}{l}\text { Before intubation } \\
\text { After intubation }\end{array}$ & $79.01 \pm 14.14+$ & $71.33 \pm 8.20+$ & $0.018^{*}$ \\
$1^{\text {st }}$ min. & $94.20 \pm 14.79+$ & $79.73 \pm 6.87$ & $0.000^{*}$ \\
$\begin{array}{l}\text { After intubation } \\
3^{\text {rd }} \text { min. }\end{array}$ & $83.10 \pm 14.50$ & $73.50 \pm 8.16+$ & $0.003^{*}$ \\
$\begin{array}{l}\text { After intubation } \\
5^{\text {th }} \text { min. }\end{array}$ & $76.57 \pm 12.75+$ & $71.60 \pm 9.70+$ & 0.095 \\
\hline
\end{tabular}

$\mathrm{n}=30 ;+$ intragroup comparisons, level of significance $\mathrm{p}<0.05$.

Table III - Intergroup Systolic Arterial Pressure

\begin{tabular}{llll}
\hline Time & $\begin{array}{l}\text { Fentany } \\
\text { Mean } \pm \text { SD }\end{array}$ & $\begin{array}{l}\text { Dexmedetomidine } \\
\text { Mean } \pm \text { SD }\end{array}$ & $\mathrm{p}$ \\
\hline Basal values & $130.67 \pm 16.15$ & $128.57 \pm 20.05$ & 0.675 \\
Before induction & $130.01 \pm 17.50$ & $121.33 \pm 15.73+$ & 0.056 \\
$\begin{array}{l}\text { Before intubation } \\
\text { After intubation }\end{array}$ & $106.25 \pm 14.62+$ & $117.87 \pm 19.68+$ & $0.012 *$ \\
$1^{\text {st }}$ min. \\
$\begin{array}{l}\text { After intubation } \\
3^{\text {rd }} \text { min. }\end{array}$ & $117.48 \pm 14.11+$ & $116.28 \pm 16.77+$ & 0.761 \\
$\begin{array}{l}\text { After intubation } \\
5^{\text {th }} \text { min. }\end{array}$ & $105.01 \pm 13.29+$ & $104.08 \pm 12.65+$ & 0.862 \\
\hline
\end{tabular}

$n=30 ;+$ intragroup comparisons level of significance $p<0.05$; * significant at $\mathrm{p}<0.05$.

Table IV - Diastolic Pressure Comparisons between Study Groups

\begin{tabular}{llll}
\hline Time & $\begin{array}{l}\text { Fentanyl }^{\mathrm{n}} \\
\text { Mean } \pm \text { SD }\end{array}$ & $\begin{array}{l}\text { Dexmedetomidine }^{\mathrm{n}} \\
\text { Mean } \pm \mathrm{SD}\end{array}$ & $\mathrm{p}$ \\
\hline Basal values & $80.47 \pm 10.46$ & $79.04 \pm 8.23$ & 0.548 \\
Before induction & $79.83 \pm 10.60$ & $71.63 \pm 9.35+$ & $0.002^{*}$ \\
Before Intubation & $68.33 \pm 9.51+$ & $76.37 \pm 12.24$ & $0.006^{*}$ \\
$\begin{array}{l}\text { After intubation } \\
1^{\text {st }} \text { min }\end{array}$ & $89.83 \pm 12.24+88.07 \pm 11.94+$ & 0.577 \\
$\begin{array}{l}\text { After intubation } \\
3^{\text {rd } \text { min }}\end{array}$ & $77.07 \pm 10.80$ & $72.83 \pm 11.26+$ & 0.143 \\
$\begin{array}{l}\text { After intubation } \\
5^{\text {th }} \text { min }\end{array}$ & $69.27 \pm 10.18+64.23 \pm 9.14+$ & 0.049 * \\
\hline
\end{tabular}

$\mathrm{n}=30 ;+$ intragroup comparisons, level of significance $\mathrm{p}<0.05$; ${ }^{*}$ significant at $p<0.05$. 


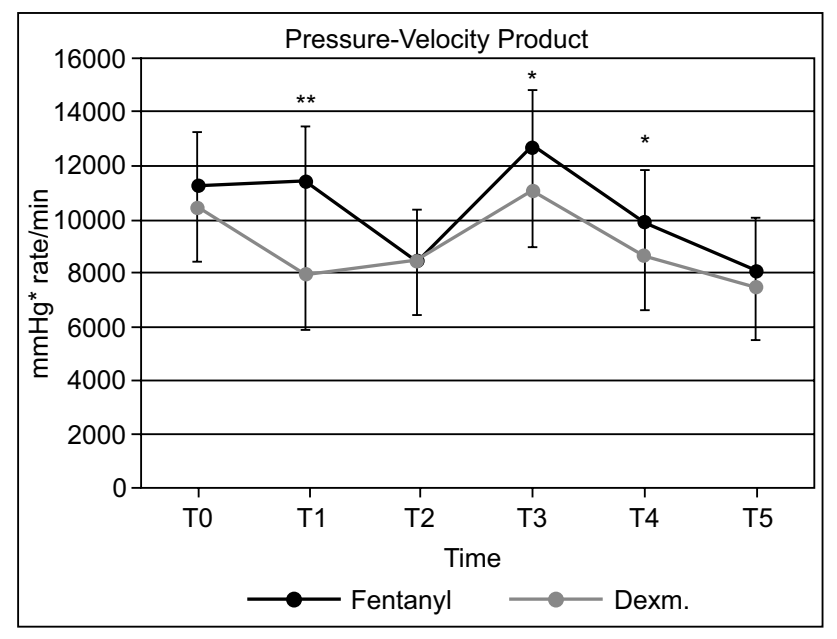

Figure 5 - Rate-Pressure Product.

* Significant at $p<0.05 ;{ }^{* *}$ Significant at $p<0.001$.

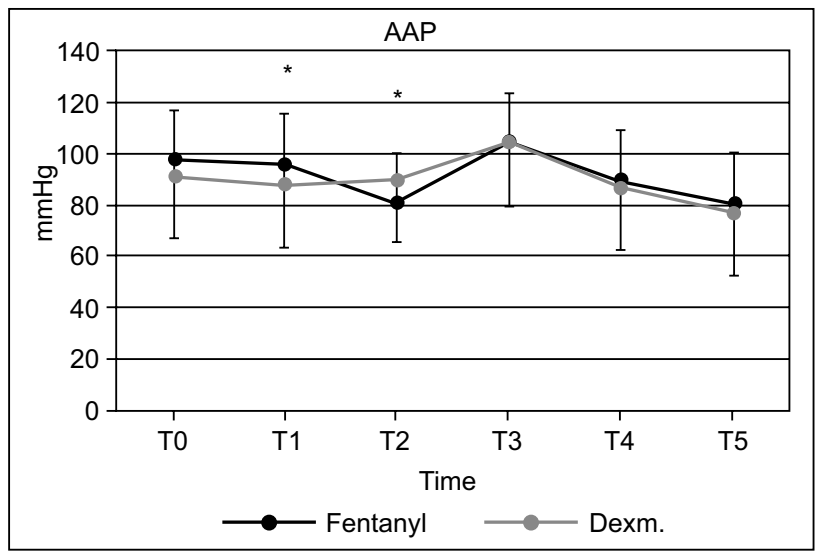

Figure 4 - Mean Arterial Pressure.

* Significant at $p<0.05$ level.

\section{DISCUSSION}

There was an evident increase in plasma norepinephrine and epinephrine levels, heart rate, and blood pressure among young chronic smokers after laryngoscopy and endotracheal intubation ${ }^{8-11}$. These hemodynamic changes can be reduced by blocking the $\alpha$-and $\beta$-adrenergic receptors ${ }^{12-14}$. It seems that the mechanisms responsible for the increase in blood pressure and heart rate are adrenergic in nature.

Grassi et al. ${ }^{1}$ suggested that sympathetic activation caused by chronic smoking may stem from increased catecholamine release and/or decreased glycerine in neuroeffector resultants. Laxton et al. ${ }^{15}$ examined the hemodynamic changes caused by laryngoscopy and tracheal intubation in chronic smokers and suggested that a high level of tachycardiac response occurs in chronic smokers. It has been proposed that subepithelial receptors in smokers are more exposed than in nonsmokers because chronic smoking changes the
Table V - Intergroup Mean Arterial Pressure

\begin{tabular}{llll}
\hline Time & Fentanyl $^{\mathrm{n}}$ & \multicolumn{2}{l}{ Dexmedetomidine $^{\mathrm{n}}$} \\
& Mean $\pm \mathrm{SD}$ & Mean $\pm \mathrm{SD}$ & $\mathrm{p}$ \\
\hline Beginning & $97.23 \pm 11.24$ & $95.58 \pm 11.16$ & 0.572 \\
Before induction & $96.50 \pm 11.95$ & $88.26 \pm 10.7+$ & $0.007^{*}$ \\
$\begin{array}{l}\text { Before intubation } \\
80.97 \pm 10.52+\end{array}$ & $90.22 \pm 14.21$ & $0.006^{*}$ \\
$\begin{array}{l}\text { After intubation } \\
1^{\text {st }} \text { min }\end{array}$ & $104.622 \pm 13.63+104.42 \pm 13.20+$ & 0.954 \\
$\begin{array}{l}\text { After intubation } \\
3^{\text {rd }} \text { min }\end{array}$ & $90.56 \pm 11.09+$ & $87.33 \pm 12.51$ & 0.294 \\
$\begin{array}{l}\text { After intubation } \\
5^{\text {th }} \text { min }\end{array}$ & $81.11 \pm 10.58+$ & $77.56 \pm 9.81+$ & 0.182 \\
\hline
\end{tabular}

$\mathrm{n}=30 ;+$ intragroup comparisons level of significance $\mathrm{p}<0.05$; * level of significance $p<0.05$.

Table VI - Intergroup Rate-Pressure Product

\begin{tabular}{llll}
\hline Time & $\begin{array}{l}\text { Fentanyl }^{\mathrm{n}} \\
\text { Mean } \pm \text { SD }\end{array}$ & $\begin{array}{l}\text { Dexmedetomidine } \\
\text { Mean } \pm \text { SD }\end{array}$ & $\mathrm{p}$ \\
\hline Beginning & $11,205.43 \pm$ & $10,411.50 \pm$ & 0.329 \\
& $3,149.67$ & $2,939.37$ & \\
Before induction & $11,395.52 \pm$ & $7,849.12 \pm$ & $0.000^{*}$ \\
& $3,426.19$ & $1,729.11+$ & \\
Before intubation & $8,348.57 \pm$ & $8,403.33 \pm$ & 0.892 \\
& $1,761.23+$ & $1,606.78+$ & \\
After intubation & $12,739.23 \pm$ & $11,001.85 \pm$ & $0.010^{*}$ \\
$1^{\text {st } \text { min }}$ & $3,026.56+$ & $1,899.21$ & \\
After intubation & $9,829.37 \pm$ & $8,596.40 \pm$ & 0.017 * \\
$3^{\text {rd } \text { min }}$ & $2,243.38+$ & $1,597.47+$ & \\
After intubation & $8,047.72 \pm$ & $7,444.62 \pm$ & 0.140 \\
$5^{\text {th }}$ min & $1,721.89+$ & $1,281.89+$ & \\
\hline
\end{tabular}

$n=30 ;+$ intragroup comparisons level of significance $p<0.05$; * level of significance $p<0.05$

upper airway epithelium characteristics ${ }^{15,16}$. For this reason, laryngoscopy and tracheal intubation can also induce more hemodynamic changes by possibly triggering the same pathway. It has also been reported that chronic smokers are more prone to coronary artery disease than nonsmokers. Increases in rate-pressure product can even further increase both the myocardial oxygen requirement and ischemia in patients with ischemic heart disease 17,18. Cuvas et al. ${ }^{19}$ suggested that determining the smoking history of the patient is important for preoperative evaluation and that chronic smokers are particularly high-risk patients. It has been emphasized that ischemic heart disease and increased post-intubation myocardial oxygen requirement increases the cardiac risk ${ }^{19}$.

Dexmedetomidine is an $\alpha-2$ agonist that decreases sympathetic activity and reduces pain ${ }^{20,21}$. There is report on the use of dexmedetomidine instead of fentanyl 22,23 . The use of dexmedetomidine in anesthesia regimes to deepen the effect of 
anesthesia has increased among anesthesiologists and intensive care doctors ${ }^{24}$. However, it has been reported that high concentrations of dexmedetomidine increase the anterior and posterior weight of the heart ${ }^{25}$. Blood pressure decreases with the central effect of the $\alpha 2$-adrenoreceptor agonists and as a result of the increase in norepinephrine synthesis in peripheral presynaptic $\alpha 2$-receptors ${ }^{26}$. Additionally, $\alpha 2$-adrenoreceptor agonists create peripheral vasoconstriction by directly activating the $\alpha 2$-receptors in vascular smooth muscles ${ }^{27}$. For this reason, the hemodynamic effects of $\alpha 2$-adrenoreceptor agonists are a result of their central sympatholytic and peripheral vasoconstrictive effects.

The most important issue related to the use of dexmedetomidine is its hemodynamic side effects. Although bradycardia and hypotension are the most common side effects, dexmedetomidine also presents a biphasic, dose-dependent, blood pressure response similarly to other $\alpha 2$-adrenoreceptor agonists. High doses when first administered result in a temporary blood pressure increase and reflex decrease in heart rate. This increase in blood pressure in the beginning may be related to dexmedetomidine rate of infusion and its high concentration ${ }^{28}$. The hypertensive effect that is visible when the dose is first administered is followed by temporary sympathetic depression ${ }^{29}$. Özköse et al. ${ }^{30}$ infused dexmedetomidine at a dose of $1 \mu \mathrm{g} \cdot \mathrm{kg}^{-1}$ over 10 minutes and reported no biphasic effect on blood pressure. In the study, it was not observed any biphasic effect because the dose was administered at a lower concentration and infused more slowly than has been previously reported.

The increase in blood pressure began after approximately 15 seconds and reached its maximum level after $30-45$ seconds ${ }^{31}$. It was possible to concluded that evaluations during the first minute after administration, in which the greatest degree of blood pressure change occurs, are important. In the group receiving dexmedetomidine, according to the basal values recorded, an increase of $7 \%$ in systolic pressure, $1 \%$ in diastolic blood pressure, and $9 \%$ in mean blood pressure occurred in the first minute after intubation. Apart from that, it was observed that the hemodynamic response is stabilized. In a study by Aantaa et al. ${ }^{32}$, dexmedetomidine was administered 15 minutes before anesthetic induction at doses of 0.35 $0.67 \mathrm{mcg} \cdot \mathrm{kg}^{-1}$, and they reported a mean decrease in systolic and diastolic blood pressure. These decreases were not dosedependent and reached maximum level after 10 minutes ${ }^{32}$.

Bradycardia resulting from dexmedetomidine may initially be triggered by baroreflex activity; however, subsequent decreases in heart rate primarily derive from central sympathetic depression ${ }^{29}$.

Özköse et al. ${ }^{30}$ administered a $1 \mu \mathrm{g} \cdot \mathrm{kg}^{-1}$ dose of dexmedetomidine over 10 minutes and observed atropine-requiring bradycardia in 4 of 20 patients. Aho et al. ${ }^{33}$ reported that the use of $2.4 \mu \mathrm{g} \cdot \mathrm{kg}^{-1}$ intramuscular dexmedetomidine resulted in endotracheal intubation in 8 of 20 patients who underwent gynecological laparoscopy. In the study, heart rates decreased by $20 \%$ after the administration of dexmedetomidine. However, no bradycardia requiring treatment was observed. There was no statistically significant change in heart rates com- pared with the basal values measured one minute after intubation. The fact that no bradycardia requiring treatment was observed, even though the same doses as Özköse et al. ${ }^{30}$ suggests were used, these results may be related to the high sympathoadrenal response of chronic male smokers.

Because tachycardia, which develops after tracheal intubation, is more closely related to myocardial ischemia than hypertension, another parameter used for monitoring the heart's workload is the rate-pressure product. Rate-pressure product, which is frequently utilized as an indicator of the myocardial oxygen requirement, is a numeric value obtained by multiplying heart rate by systolic blood pressure. Its upper limit is $12000-15000$, which is the critical threshold and indicates cardiac ischemia ${ }^{34,35}$.

In a study of normotensive patients with coronary artery disease, Gobel et al. ${ }^{36}$ emphasized that rate-pressure product is a significant parameter for determining oxygen demand and consumption by the heart during exercise. Kaplan et al. ${ }^{37}$ suggested that the rate-pressure product causes ischemic electrocardiographic changes when it is over 12000 in patients with history of coronary artery surgery. Willigers et al. ${ }^{34,38}$ reported in their study that dexmedetomidine has the potential to suppress some of the cardiovascular and neuroendocrine changes caused by sympathetic stimulation and to decrease systolic pressure and heart rate, which are indications that myocardial oxygen is required. They also found that the ratepressure product decreases as a result ${ }^{39}$. In a study using $22 \mu \mathrm{g} . \mathrm{kg}^{-1}$ single-dose dexmedetomidine, Lawrence et al. ${ }^{28}$ did not observe any statistically significant change in the dexmedetomidine group regarding heart rate or rate-pressure product after endotracheal intubation as compared to the beginning of the process. They reported that dexmedetomidine decreased the hemodynamic response associated with tracheal intubation. In the study, no changes were observed in heart rate or rate-pressure product after dexmedetomidine infusion in the first minute of intubation. We calculated the ratepressure product as 11011 when the response to tracheal intubation was the highest. This value was lower than 12000 , which is the upper limit for ischemia. Willigers et al. ${ }^{34}$ also showed that dexmedetomidine decreases the rate-pressure product at approximately $26 \%$ after infusion. In the study, the rate-pressure product decreased at approximately $24 \%$.

Low-dose fentanyl is widely used to increase the response to laryngoscopy and tracheal intubation. Saliho lu et al. ${ }^{31}$ compared the effects of fentanyl, alfentanil, and remifentanil in morbidly obese patients. They observed that a $1 \mu \mathrm{g} \cdot \mathrm{kg}^{-1}$ dose of fentanyl, which is expected to decrease the hemodynamic response to intubation, decreased blood pressure and heart rate. No significant side effects were observed ${ }^{31}$. In their study, Katoh et al. ${ }^{40}$ found that $2 \mu \mathrm{g} . \mathrm{kg}^{-1}$ of fentanyl prevents an increase in blood pressure and heart rate during tracheal intubation. Cuvaș et al. ${ }^{19}$ found that $1.5 \mu \mathrm{g} \cdot \mathrm{kg}^{-1}$ fentanyl did not prevent an increase in heart rate and rate-pressure product values in chronic male smokers ${ }^{41,27}$. Kovac et al. ${ }^{2}$ reported that 5 minutes before intubation is the most effective time for fentanyl administration to prevent hemodynamic responses to tracheal intubation in healthy patients. Chung et al. ${ }^{42}$ reported 
that $3 \mu \mathrm{g} \cdot \mathrm{kg}^{-1}$ fentanyl prevented increases in blood pressures and heart rate in the first minute after intubation ${ }^{42}$. Adachi et al. ${ }^{43}$ suggested that fentanyl suppresses the response to intubation more effectively than the hemodynamic response associated with laryngoscopy. lyer et al. ${ }^{44}$ suggested that a $3 \mu \mathrm{g} . \mathrm{kg}^{-1}$ dose of fentanyl prevents mean blood pressure increase compared to high-dose induction values; a $10 \mu \mathrm{g} . \mathrm{kg}^{-1}$ dose is necessary to prevent an increase in heart rate. However, the use of fentanyl in high doses causes adverse side effects such as hypotension, post-operative prolonged respiratory depression, nausea, vomiting, and muscle rigidity. In the study, it was observed that $3 \mu \mathrm{g} . \mathrm{kg}^{-1}$ fentanyl did not prevent increases in heart rate or rate-pressure product one minute after intubation. One minute post-intubation, the rate-pressure product value obtained for the fentanyl group was 12,746 . This value is near the upper limit for myocardial ischemia. This result suggests that chronic smokers may exhibit an increased sympathoadrenal response and that fentanyl used to prevent increased heart rate is inadequate.

Consequently, dexmedetomidine administered in a $1 \mu \mathrm{g} \cdot \mathrm{kg}^{-1}$ dose 10 minutes before anesthesia induction in chronic male smokers (from whom high response to laryngoscopy and tracheal intubation is expected) suppresses increased heart rate and rate-pressure product at 1 and 3 minutes after intubation and, therefore, decreases the need for myocardial oxygen more than fentanyl. 


\section{REFERÊNCIAS/REFERENCES}

1. Grassi G, Seravalle G, Calhoun DA et al. - Mechanisms responsible for sympathetic activation by cigarette smoking in humans. Circulation, 1994;90:248-253.

2. Kovac AL - Controlling the hemodynamic response to laryngoscopy and endotracheal intubation. J Clin Anesth, 1996;8:63-79.

3. Shribman AJ, Smith G, Achola KJ - Cardiovascular and catecholamine responses to laryngoscopy with and without tracheal intubation. $\mathrm{Br} \mathrm{J}$ Anaesth, 1987;59:295-299.

4. Finfer SR, MacKenzie SI, Saddler JM, Watkins TG - Cardiovascular responses to tracheal intubation: a comparison of direct laryngoscopy and fiberoptic intubation. Anaesth Intensive Care, 1989;17:44-48.

5. Bishop MJ, Harrington RM, Tencer AF - Force applied during tracheal intubation. Anesth Analg, 1992;74:411-414.

6. Slogoff S, Keats AS - Does perioperative myocardial ischemia lead to postoperative myocardial infarction? Anesthesiology, 1985;62:107114.

7. Jee $\mathrm{D}$, Moon $\mathrm{HL}-$ Gender may affect the hemodynamic response to induction and intubation in young adults. J Clin Anesth, 2003;16;563567.

8. Che $\mathrm{S}-$ Actions of nicotine and smoking on circulation. Pharmacol Ther, 1982;17:129-141.

9. Groppelli A, Giorgi DMA, Omboni S, Parati G, Mancina G - Persitent blood pressure increase induced by heavy smoking. J.Hypertens, 1992;10:495-499.

10. Baer L, Radichevich I - Cigarette smoking in hypertensive patients. Am J Med. 1985;78:564-568.

11. Trap-Jensen L, Carlen JE, Svensen TL, Christensen NS - Cardiovascular and adrenergic effects of smoking during immediate non-selective beta-adrenoreceptor blockade in hummans Eur J.Clin Invest, 1979;9;181-183.

12. Trap-Jensen $\mathrm{J}$ - Effects of smoking on the heart and peripheral circulation Am Heart J, 1988;115:258-263.

13. Winniford MD - Smoking and cardiovascular function. J Hypertens, 1990;9(suppl 5):17-23.

14. Groppelli A, Giorgi DMA, Omboni S, Parati G, Mancina G - Blood pressure and heart rate response to repeated smoking before and after betablockade and selective alpha 1 -inhibation function $\mathrm{J}$ Hypertens, 1990;8(suppl 5):35-40.

15. Laxton $\mathrm{CH}$, Milner Q, Murphy PJ - Haemodynamic changes after tracheal intubation in cigarette smokers compared with non-smokers. $\mathrm{Br}$ J Anaesth, 1999;82(3):442-443.

16. Erskine RJ, Murphy PJ, Langton JA - Sensitivity of upper airway reflexes in cigarette smokers: effect of abstinence. $\mathrm{Br} \mathrm{J}$ Anaesth, 1994;73:298-302.

17. Fitz-Henry J, Curran J, Griffiths D - Smokers and haemodynamic response to desflurane. Anaesthesia, 1999;54:800-803.

18. McBride PE - The health consequences of smoking-cardiovascular disease. Med Clin North Am, 1992;76:333-353.

19. Cuvaș O, Er A, Ikeda OC, Dikmen B, Ba ar H - Cigarette smoking and the haemodynamic response to tracheal intubation. Anaesthesia, 2008;1365-2004.

20. Jaakola ML, Kanto J, Scheinin H, Kallio A. - Intramuscular dexmedetomidine premedication - an alternative to midazolam-fentanylcombination in elective hysterectomy? Acta Anaesthesiol Scand, 1994;38:238-243.

21. Jaakola ML - Dexmedetomidine premedication before intravenous regional anesthesia in minor outpatient hand surgery. $\mathrm{J}$ Clin Anesth, 1994;6:204-211.

22. Feld JM, Hoffman WE, Stechert MM, Hoffman IW, Ananda RC - Fentanyl or dexmedetomidine combined with desflurane for bariatric surgery. J Clin Anesth, 2006;18:24-28. 
23. Hofer RE, Sprung J, Sarr MG, Wedel DJ - Anesthesia for a patient with morbid obesity using dexmedetomidine without narcotics. Can J Anaesth, 2005;52:176-180.

24. Paris A, Tonner PH - Dexmedetomidine in anaesthesia. Curr Opin Anaesthesiol, 2005;18;412-418.

25. Ebert TJ, Hall JE, Barney JA, Uhrich TD, Colinco MD - The effects of increasing plasma concentrations of dexmedetomidine in humans. Anaesthesiology, 2000;93:382-394.

26. Flacke JW - $\alpha 2$-adrenergic agonists in cardiovascularanesthesia $\mathrm{J}$ Cardiothorac Vasc Anesth, 1992;6:344-359.

27. Chen DG, Dai XZ, Zimmerman BG, Bache RJ - Postsynaptic $\alpha 1$ and $\alpha 2$ - adrenergic mechanism in coronary vazoconstruction $\mathrm{J}$ Cardiovasc Pharmacol, 1988;11:61-67.

28. Lawrence CJ, De Lange S - Effects of a single perioperative dexmedetomidine dose on isoflurane requiretmens and perioperative haemodynamic stability. Anaesthesia, 1997;52:736-744.

29. Xu H, Aibiki M, Seki K, Ogura S, Ogli K - Effects of dexmedetomidine, an $\alpha 2$ adrenoceptor agonist,on renal sympathetic nerve activity,blood pressure, heart rate and central venous pressure in urethane-anesthetized rabbits. J Auton Nerv Syst, 1998;71:48-54.

30. Özköse Z, Demir FS, Pampal K, Yardım S - Hemodynamic and anesthetic advantages of dexmedetomidine, $\alpha 2$ agonist for surgey in prone position. Tohoku J Exp Med, 2006;210:153-160.

31. Saliho lu Z, Demiroluk S, Demirkiran, Kose Y - Comparison of effects of remifentanil, alfentanil and fentanyl on cardiovascular responses to tracheal intubation inmorbidly obese patients. Eur J Anaesthesiol, 2002;19(2):125-128.

32. Aantaa RE, Kanto JH, Scheinin M, Kallio AMI, Scheinin H - Dexmedetomidine Premedication for Minor Gynecologic Surgery. Anesth Analg, 1990;70:407-413.

33. Aho M, Scheinin M, Lehtinen AM, Erkola O, Vuorinen J, Korttila K - Intramuscularly administered dexmede tomidine attenuates hemodynamic and stress hormone responses to gynecologic laparoscopy. Anesth Analg, 1992;75:932-999.

34. Willigers HM, Prinzen FW, Roekaerts HJ - Comparison of the effects of dexmedetomidine and esmolol on myocardial oxygen consumption in dogs. E J A, 2004;21(12):957-966.

35. Kayhan Z - Kardiyovasküler Sistem ve Anestezi. Klinik Anestezi, 3th edition, Logos Press: p. 308-10, Istanbul, 2004.

36. Gobel FL, Norstrom LA, Nelson RR - The rate-pressure product as an index of myocardial oxygen consumption during exercise in patients with angina pectoris. Circulation, 1978;57(3):549-556.

37. Kaplan JD, Schuster DP - Physigolic consequences of tracheal intubation.Clınics in Chest Medicine, 1991;12(3):425-432.

38. Willigers HM, Prinzen FW, Roekaerts PMHJ - The Effects of esmolol and dexmedetomidine on myocardial oxygen consumption during sympathetic stimulation in dogs. J Cardiothorac Vasc Anesth, 2006;20(3):364-370.

39. Hoeft A, Sonntag H, Stephan H, Kettler D - Validation of myocardial oxygen demand indices in patients awake and during anesthesia. Anaesthesiology, 1991;75;48-56.

40. Katoh T, Nakajima $\mathrm{Y}$, Moriwaki $\mathrm{G}$ et al. - Sevoflurane requiretments for tracheal intubation with and without fentanyl. $\mathrm{Br} \mathrm{J}$ Anaesth, 1999;82(4):561-565.

41. Sear JW - Recent advances and developments in the clinical use of iv opioids during the peroperative period. Br.J.Anesth.,81:38-50; 1998.
42. Chung F, Evans D - Low-dose fentanyl: Haemodynamic response during induction and intubation in geriatric patients. Can Anaesth Soc J, 1985;32:622-628.

43. Adachi YU, Satomoto M, Higuchi $H$, Watanabe $\mathrm{K}$ - Fentanyl attenuates the hemodynamic response to endotracheal intubation more than the response to laryngoscopy. Anest. Analg, 2002;95(1):233-237.

44. Iyer V, Russell W - Induction using fentanyl to suppress the intubation response in the cardiac patient: what is the optimaldose? Anaesth Intens Care, 1988;16:411-417. 